\title{
Embracing obscurity: The enigmatic walk of the Son of God in Mark
}

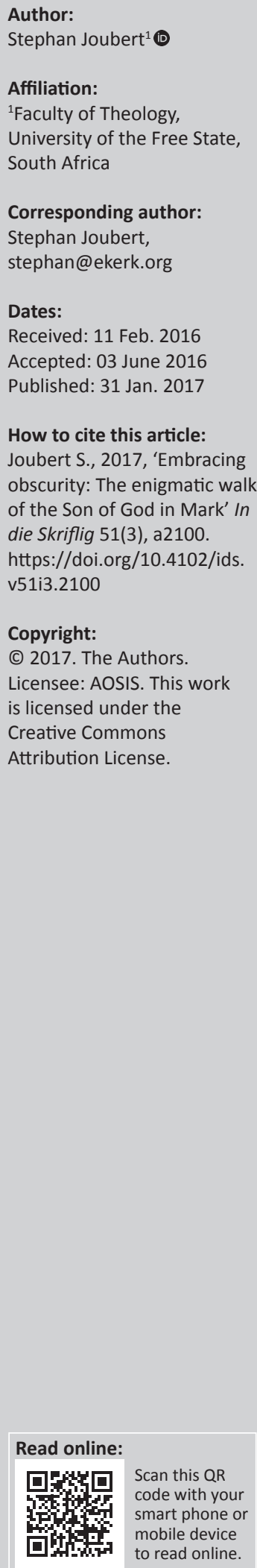

\begin{abstract}
When Greco-Roman deities appeared among human beings in anthropomorphic shapes, their outward form and gait soon revealed their true identity. By contrast, the Markan Jesus has no 'inescapably divine' demeanour. His unassuming presence, his hurried walk and his interactions with people of low public standing and honour place a constant question mark over his identity. Paradoxically, his purposeful walk in obscurity, which ends on the cross, reveals his true character as the suffering Son of God who ransoms his life for many. The risen Jesus, whose divine nature Mark does not express in terms of a glorified body, continues his enigmatic walk before his disciples en route to Galilee.
\end{abstract}

\section{Interacting with the divine in Greco-Roman antiquity}

When deities appeared in the ancient Greco-Roman world, they often adopted human shapes. These anthropomorphic forms enabled individuals to interact with them. However, goddesses and gods did not simply aspire:

... to imitate the human bodily form, they frequently exceeded it both in size and by turning the divine state into something more perfect and gleaming than the human body. (Kindt 2012:44)

Their cĩ $\delta o \varsigma$ ('eidos'), that is their outward form or visible identifying features, such as the radiance, fragrance and beauty emanating from their bodies reflected their divine identity.

Deities moved, talked and dressed differently from human beings. Their gait was '... inescapably divine' (Jenkyns 2013:148). Even when they tried to disguise themselves, such as the goddess Venus who takes on the appearance of a huntress in Virgil's Aeneas (I. 405), their incessus or gait eventually revealed their true identity. The same happened when Poseidon disguised himself as a priest. One of the Ajaxes recognises him and mentioned that he easily identified his steps and gait when he moved, 'because gods are well distinguishable' (Il. 13.45-72). Dionysus, the most visible and immediately present of all the gods, the deus praesentissimus so to speak (cf. Kobel 2011:237-238), also loved to appear in disguised form, but his demeanour, gait and dress frequently gave away his identity. Individuals such as Acoetes in Ovid's Metamorphoses (3.609-610) know that they do not resemble mortal men. It seems that deities actually expected people to recognise them in spite of their human disguises. Athena rebukes Odysseus who does not recognise her in her disguise, while Pentheus, who fails to recognise Dionysus when he once showed up in human disguise, has to die (Kobel 2011:237).

In the ancient Mediterranean world, epiphanies were visual encounters, albeit in dreams or visions, while people were awake. The eyes of those with whom deities chose to interact were enlightened to both allow for their recognition and facilitate the necessary $\theta \dot{\alpha} \mu \beta 0 \varsigma$ or astonishment. ${ }^{1}$ These visual manifestations of deities served as the basic system of reference in terms of how people came to know and interpret the divine. The memory of such encounters was expressed in poems, epic stories, votive reliefs, and so on, but also by means of various symbolic expressions and actualisations of the divine in sanctuaries and rituals. ${ }^{2}$

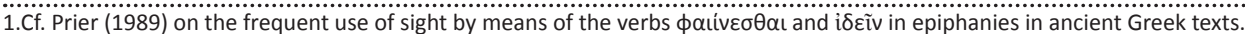

2.Sanctuaries served as sacred spaces, since they were ' ... clearly marked from non-sanctuary space, and boundary markers designate (d) its circumference' (Graf 2010:61). Anthropomorphic statues of the gods in their temples and elsewhere made them visibly present and recognisable, and facilitated interaction with them. At the same time, Henrichs (2010) comments: once a particular deity became iconographically identified with his or her cult image, the relationship between god and image was reversed; as a result gods were iconographically identified with his or her cult image, the relationship between god and image was reversed; as a result gods were
often believed to make their epiphanies in the likeness of their statues (p. 33). By means of these visual representations of deities, which were also incorporated into a variety of rituals, such as 'epiphany dreams' and incubations in shrines (Harris 2008:39), people believed that they could connect the divine universe with the necessities of everyday life. Thus, as visible representations of the gods statues not only established a physical 'mnēma' or a visible memory, but also served as physical activations of their presence. 


\section{Jesus, the enigmatic Son of God in Mark}

Contrary to the radiant epiphanies of Greco-Roman deities, or their splendorous gait that frequently gave away their divine nature when they appeared in disguised forms, the Gospel of Mark presents Jesus very differently. Mark makes no explicit mention of extravagant garments, physical posture, demeanour, or comportment befitting the divine status Jesus

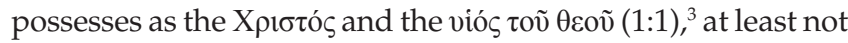
in terms of stereotypical ancient Mediterranean expectations. The Gospel offers no genealogy of Jesus (or any kind of cursus honorum), nor any description of his gait as a proper reflection of his divinity. In the words of Carroll (2007):

Jesus is the archetypal stranger. He appears from nowhere, shrouded in mystery, but soon is gone ... He is the existential hero - solitary, uprooted from family and home, restless, always on the move and, until the mid-point of his mission, blind to where he is going. He has no occupation, nor worldly power. (p. 1)

The Markan Jesus is an atvry $\mu \alpha$, a prophetic riddle in human form.

The story of this enigmatic Jesus, which unfolds in three movements (1:1-8:26: the Galilean ministry; 8:27-10:52: Jesus en route to his Passion; and 11:1-16:8: Jesus in Jerusalem), is

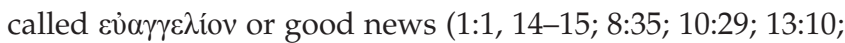
14:9). France (2002) remarks:

Mark tells the story of a recent historical figure in such a way as to commend the man and his message, and to summon those who read or hear it to follow him as his first disciples were called to do. (p. 10)

Still, Jesus is deceptively different from the popular biographies of famous Greco-Roman figures in terms of his a-typical outward appearance and shameful crucifixion on the one hand, and his resurrection and veneration on the other.

At the beginning of the Gospel, God publicly reveals the divine nature of Jesus at his baptism (1:9-11). He does this vocally by means of 'an honor designation of the highest

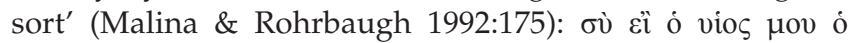
$\dot{\alpha} \gamma \alpha \pi \eta \tau$ ó $\varsigma$ [you are my beloved son $-1: 11$ ]. However, in this instance no outward signs of a lofty physical presence advertise the divinity of Jesus. All one reads is that the Spirit comes upon him in a dove-like motion. ${ }^{4}$ Mark never concerns himself with the 'preexistent nature' of Jesus. For him it is an accepted fact that Jesus is the Anointed One; this is affirmed by the descent of the Spirit upon him. He does not imply that Jesus at his baptism is physically transformed into a divine man, a $\theta \varepsilon \tilde{\text { õ }} \grave{\alpha}^{\alpha} v \eta \dot{\rho} \rho$, but rather that ' ... the descent of the Spirit upon Jesus connotes his empowerment with divine authority for messianic ministry' (Kingsbury 1983:65).

In the transfiguration scene on the mountain in Mark 9:2-8, God once again affirms the heavenly identity of Jesus: ovĩó 3.Bible texts with only reference to the chapter and verse, come from the Gospel of Mark. 4.The phrase, દiç aủtóv, could grammatically be translated as 'towards him', 'into him', or 'upon him'. The latter seems the more appropriate in this instance.

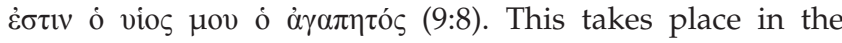
presence of Moses and Elijah, both of whom make a postmortem appearance as the most important figures of Judaism and the official representatives of Israel's law and prophets. Also present are Peter, James and John, as the inner circle of the disciples and representatives of all future followers of Jesus. Only in this instance in Mark, a brief metamorphosis or transfiguration of Jesus' body takes place, but he is still recognisable. 'Jesus' transfigured glorious body with the white clothes reinforces Jesus belonging to the heavenly realm; and God's own divine testimony to Jesus' Sonship reaches the climax of the story' (Lee 2009:12). ${ }^{5}$

After Peter's earlier confession that Jesus is the Christ in Caesarea-Philippi (8:27-30), as well as Jesus' first shocking announcement of his impending suffering and death as the Son of man (8:31-33), God now publicly assures the disciples that Jesus is his beloved son (cf. also Morrison 2015:148 ff.). ${ }^{6}$ This is an epiphanic moment where the identity of Jesus is confirmed once again, but only his inner circle witness this exclusive metamorphosis of Jesus in the Gospel. Yet the only outward differences noticed by Mark are Jesus' shiny garments (v. 3), and as the use of the verb $\mu \varepsilon \tau \alpha \mu \rho \rho \varphi$ ó indicates, the glory radiating from his body and face. No, this is not a misplaced account of resurrection as some researchers suspect. Mark wants to stress the point that Jesus' outward

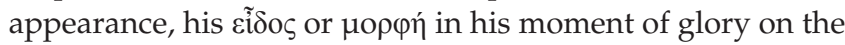
mountain where his true divine presence is displayed, is not unrecognisably different from his 'normal' appearance throughout his public ministry. He is who he is and looks like he does in the presence of both human beings and God, even after his resurrection from the dead. Unlike the other Gospels, Mark gives no indication of a glorious post resurrection body for Jesus. Thus the enigmatic Markan Jesus does not have a different divine persona, alter ego, or even a significantly different physical appearance in his glorified form than during his conventional appearances.

\section{The true identity of Jesus is displayed in his unassuming appearance}

The Gospel of Mark is written for a predominantly nonJewish audience:

Dies ergibt sich schon aus der bereits erwähnten Erklärung jüdischer Bräuch und der Übersetzung semitischer Ausdrücke. Das Fehlen des Terminus nomos und die Aufnahme von Gesetzesstoffen zeigen deutlich, dass in der markinschen Gemeinde das Gesetz nicht mehr als Kultgesetz, sondern nur noch als Moralgesetz relevant war (cf. Mk 10, 1-12.17-27; 12, 28-34). (Schnelle 2013:270)

5.Tàrech (2012) states: Jesus has been formally shown as a heavenly and glorious figure close to God and belonging to the heavenly realm. He is the Messiah of Israel as Peter had recognized (Mark 8:29), but also someone who belongs to the divine word, and it is God who proclaims him to be such by transfiguring him (9:3). Jesus' identity in its profoundest aspect is not of this earth, and his choice of a future beset by suffering and death, which he has openly expressed to the disciples, is part of his destiny (pp. 165-166).

6.It is doubtful that this is a 'pivotal mandatory epiphany' (Heil 2000:51ff.). The suggestion of Moss (2004:69ff.) that the transfiguration story is a typical epiphany, along the lines of Hellenistic descriptions, but also mixed with the influence of along the lines of Hellenistic descriptions, but also mixed with the influence of
Exodus 24 and 1 Kings 19, seems plausible given the mixed nature of the first readers of the Gospel.

7.See detailed discussions on the original audience of Mark in Donnahue and Harrington (2002:34ff.), Garland (2015:68-80; Shively (2012:6ff. \& Winn 2008:148ff.). 
It is not known whether these first readers resided in Rome or in Antioch, but they at least had a working knowledge of Jewish customs, apocalyptic thought, laws and Scriptures, as well as the basic geography of Palestine. At the same time, since the first readers of Mark also shared the general stock of knowledge and stereotypical beliefs of their day regarding the expected 'eidos' of any messianic contender or divine figure, Jesus' a-typical demeanour, behaviour and gait would have been perplexing to them, to say the least. No wonder Mark's narration of Jesus as the enigmatic Son of God frames the basic question that occupies the minds of all who encounter him throughout the Gospel. The people from Capernaum (1:27), the scribes (2:7), the disciples (4:41), the inhabitants of Nazareth $(6: 2-3)$, and the high priest (14:61) speculate about the true identity of Jesus. In the words of Thielman (2005):

all three major groups in the gospel - the populace, the antagonistic Jewish leaders, and the disciples - from the beginning of the gospel to its conclusion want to know who Jesus is. (p. 58)

Whereas in Mark the religious opponents of Jesus are convinced that he is a demon-possessed blasphemer who deserves the ultimate shameful death, the people of Capernaum where Jesus lives during the Galilean phase of

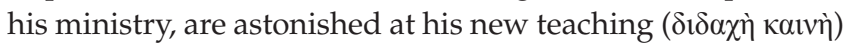

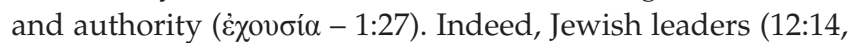
$19,32)$, his disciples $(4: 38 ; 9: 39 ; 10: 35 ; 13: 1 ; 14: 14)$, and others alike view this stranger with authority over demons as a

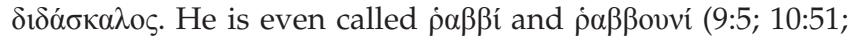
$11: 21 ; 14: 475)$, while he is frequently described as 'teaching'

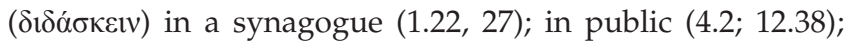
privately $(8.31 ; 9.31)$, and in the temple $(11.17 ; 12.35 ; 14.49)$ (Beavis 2015:58). Despite all this Jesus does not fit the general profile of a divine figure or a messiah, at least not from the perspective of his opponents. However, there is a hint of recognition of his real identity at the beginning of the Gospel when one reads in 1:27 that the locals of Capernaum are astounded ( $\dot{\varepsilon} \theta \alpha \mu \beta \eta \dot{\theta} \theta \sigma \alpha v)$ at his teaching and mighty deeds. $\theta \dot{\alpha} \mu \beta \mathrm{o}_{\text {is }}$ is often used in Greek mythological narratives when mortals witness the appearance of a god or goddess (Buxton 2010:85). ${ }^{8}$ It expresses a mixture of fear and astonishment in the presence of the sacred. The reaction of the people of Capernaum serves at least as a cue (to the implied readers) regarding the true nature of Jesus and the expected response to his person and message.

Paradoxically the identity of Jesus as Son of God is revealed in his unassuming presence. His powerful words and miraculous works throughout Mark only make sense from the perspective of faith. Thus the crowds and the disciples continue to be amazed and filled with fear in the presence of

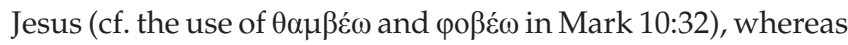
the religious leaders, who adhere to entirely different codes of religious purity, find no proof of God's presence in his scandalous teachings and inglorious outward appearance.

8.Although wonder is indicative of an epiphany, such reactions are often "... bette constituted as responses to "divine interventions" rather than "divine epiphanies" (Dwyer 1996:31).
Without any external distinguishing marks to confirm his messianic claims, they are convinced that Jesus is in fact the devil incarnate (3:22). 'Not only does this judgment throw a total discredit on Jesus' activity, but it is practically an accusation of sorcery, or demonic activity liable to the penalty of death (Exod 22:17; Lev 20:6, 27; Deut 18:10-11)' (Focant 2012:143). Even his family members are upset by his strange behaviour (3:20-21) such as his frequent physical contact with the religiously impure, including lepers (1:40-44), tax collectors (2:13-17), and non-Jews (7:24-37), as well as his repeated interactions with socially undesirable types such as peasants $(1: 38-39,45)$. This behaviour does not communicate any sensitivity for his honour, or that of his family. In addition Jesus does not adhere to the general expectations associated with 'god-spotting' in the ancient Mediterranean world, and ultimately he pays for it with his own life.

Jesus also partakes in the ongoing speculation regarding his identity during his public ministry when He asks his disciples

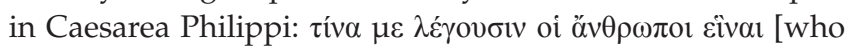
do the people say that I am? - 8:27]. This is followed by an

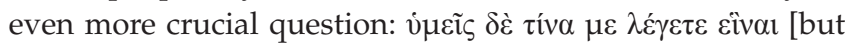
who do you say that I am? - v. 29]. Then follows Peter's

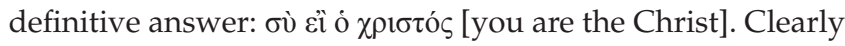
Mark's aim is to move the readers of his Gospel to a similar confession. However, against the backdrop of the pervasive physiognomic consciousness in the Mediterranean world, they need faith in order to recognise the divine identity of Jesus behind his unassuming outward appearance. In the words of Mark 3:35, as the first of a series of gnomic sayings (cf. also 9:37-42; 10:29-31; 43, 45; 11:23), they also have to do the will of God if they want to be included in the new family of Jesus.

\section{That enigmatic 'Jesus walk'}

Mark tells us that Jesus is constantly on the move (e.g. 1:9, 12, $14,21,29,35 ; 2: 13,23)$. Significantly though, he makes no explicit mention of a moderated walk on Jesus' part in a world where comportment, posture, movement, and gesture served as visible reflections of a person's identity, character and status. According to O'Sullivan (2011:21) the ideal male always walked 'slowly, with total control, his head and shoulders upright and confident, metaphorically towering over those beneath him'. Nobles in particular, walked differently from ordinary people. They were raised to walk slowly, but then again 'not too slow, for that marks a lack of effectiveness' (Corbeill 2004:122; cf. also Aristotle [Eth. Nic. 1125a]; Cicero [de Off 1.131]). ${ }^{9}$

The Markan Jesus constantly deviates from this norm. He is always on the move and often in a hurry, as can be deduced from Mark's frequent use of terms of motion. According to Best (quoted in Gray 2008:13), Mark 'uses verbs of motion more frequently than any other evangelist'. In particular the

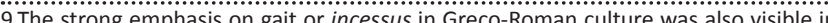
the Jewish world '... Thus Philo could state that a slave possessed a "naturally slavish body" (Quod Omn 40), while The Testament of Naphtali (2.2-9) could devote a long body" (Quod Omn 40), while The Testament of Naphtali (2.2-9) could devote a long
discussion to the correlation between outer appearance and character' (Joubert discussion to the corre
2015:footnote 13). 
motif of the ódó (the way or road) plays a prominent part in the Gospel and is used 17 times. This evokes the constant

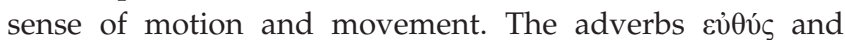

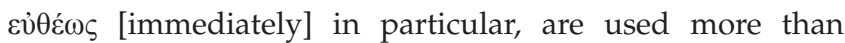
40 times in Mark, over against the five instances in Matthew, one in Luke, and three in John. ${ }^{10}$ The frequent repetition thereof within and between various episodes throughout the Gospel, coupled with the rush of narrated events, creates the impression of a very busy Jesus (cf. Shiner 2003:93-94). According to Wallace (1995):

Jesus' sudden and disorienting appearances, the disciples' and the crowd's amazement at his mighty works - all these motifs are held together by a sense of immediacy and alarm by the kai euthus phrase. (p. 48)

Urgency is the order of the day in his public ministry, or as Hanks (2009:24) puts it: 'Like Mark himself, Jesus is seen in this Gospel as being characteristically “in a hurry"'. However, these descriptions of a 'fast-paced' Jesus who hurries to come to the rescue of the sick, the impure, the sinners, the social outcasts, as well as his disciples in their moment of need, is more than simply a Markan literary motif. To the first readers, it would have communicated the opposite of a graceful, quiet or relaxed gait indicative of honourable male in the ancient Mediterranean world. Hurriedness was usually associated with people of low public status, but also with the gait of slaves, since it was expected of them to go about fast. ${ }^{11}$ Commands to slaves were frequently prefaced with the imperative 'quick' (Wrenhaven 2012:58); hence the Roman expression servus currens, the running slave!

In Mark 1:12 specific bodily movements of Jesus are alluded to in a rather strange fashion when one reads that the Spirit drives or casts ( $\dot{\kappa} \kappa \beta \dot{\alpha} \lambda \lambda \varepsilon \varepsilon-1: 12$ ) him out into the wilderness directly following his baptism. This term, often used of the expulsion of unclean spirits (1:34, 39; 3:15, 22, 23, and so on), and sometimes also with overtones of coercion (5:40; 9:47; 11:5; $12: 8$ - cf. Donahue \& Harrington 2002:66) so upsets Matthew and Luke, in terms of expressing an undesirable manner of movement, that they change it to iे $\gamma \varepsilon \tau$ (Mt 4:1) and $\dot{\alpha} v \eta \chi \theta \eta$ (Lk 4:1). Over against Mark they stress that the Spirit gently led him into the wilderness. Matthew and Luke do not want to draw too much attention to what they could have perceived as the measured gait of Jesus. In their opinion a moderate, even restrained, gait on the part of Jesus would have been a better reflection of his messianic identity.

In Mark 6:45-52 another peculiar movement of Jesus is alluded to when he intends to walk past his disciples on the Sea of Galilee. Many researchers identify this as an epiphany, an instance of 'God-walking' (cf. Garland 2015:130; Gnilka 1978:269; Stein 2008:325). As is the case in Exodus 33:19-23 and 1 Kings 19:11, where God manifests himself by passing in front of Moses and Elijah, they maintain that Jesus passes by the disciples in order to manifest his divinity. However,

10.As used in Mark, eüuc may refer to sequential action or it may suggest the rapidity with which an event occurs' (Decker 2013:56).

11.Plautus tells us via one of his characters in his Poenulus (522-523) that it is the mark of a slave to run about. the disciples' failure to recognise the power of Jesus, as expressed during his earlier multiplying of the loaves and his present walking on the water, as well as in Mark's explicit reference to the hardening of their hearts (6:52), do not give a positive ring to their utter astonishment in 6:51 (Winn 2008:142; cf. however, Stein 2008:327). Not even Matthew (14:22-33), the most Jewish of all the Gospels, gives any indication that there was an intention on his part, or for that matter, on the side of Mark, to portray the 'walk by' of Jesus on the Sea of Galilee as an epiphany equivalent to that of Exodus 33 or 1 Kings 19.

Indeed, Jesus treads where only God can walk (Job 9:8, 11; Ps $77: 19$; Is 43:16). However, due to his urgency to get to Gennesaret, located south-west of Capernaum (Mk 6:53-56), and due to the fact that the disciples are indeed surviving the storm, there is no need for him to stop (cf. Martin 2005:155-156). From this perspective, Jesus' walk-by is not intended as an epiphany, but serves as an indication of Jesus'

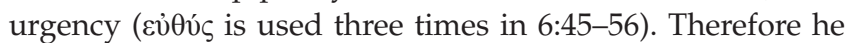
initially intends to pass them by as part of his fast-paced mission to proclaim the kingdom of God in Galilee and in the neighbouring non-Jewish territories. However, the fearful cries of the disciples persuade him to interrupt his hurried

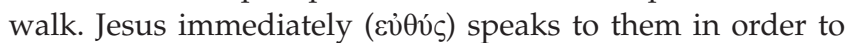
reveal his identity and to secure their safety: $\theta \alpha \rho \sigma \varepsilon i ̃ \varepsilon \cdot ~ ' \dot{\varepsilon} \gamma \omega \dot{~}$

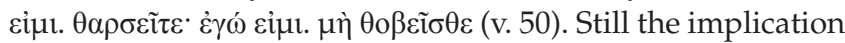
is that the disciples should have known from the start that this is Jesus, because he looks like he always does and walks as He normally does. They should also have known that they are safe in his presence after the earlier episode on the Sea of Galilee (4:35-41). Despite this he hurries to their side in their moment of fleeting faith.

Hurriedness and urgency are part and parcel of the Jesus walk' according to Mark. According to O'Sullivan (2011):

... the body that attracts attention to itself automatically excludes its bearer from the ranks of the upper-class male, and a particularly conspicuous or expressive gait - whether too fast or too slow - is an easy way to draw such attention". (p. 20)

A hurried gait goes against the grain of honourable Mediterranean males, nobles and holy figures, as noted earlier - Jesus does not fit the script. In 'slave-like' fashion he constantly hurries around and draws wanted and unwanted attention to himself as he embodies the $\varepsilon \dot{b} \alpha \gamma \varepsilon \lambda$ íov. Semiotically the walk of Jesus thus attains meaning in the framework of, and simultaneously gives meaning to his provocative words and deeds such as his transgressions of the religious purity codes of the day by touching lepers (1:40-45), forgiving sins (2:1-12), eating with sinners (2:13-17), allowing his disciples to pluck grain on the Sabbath (2:23-28), and so on.

Since it was widely accepted that one could look into the souls of others and judge their character by studying their bodily gestures (cf. Aristotle, Prior Analytics 70b6-7), and since as the well-known Jewish sage, Jesus Sirach (Sir 19:30), assumed the way a man walks shows what he is, the 'Jesus 
walk' offers Mark's readers constant glimpses into his heart

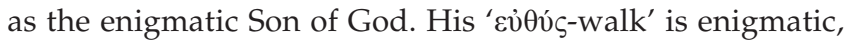
because it forces him into the same ranks as the outcasts, the sinners, the nobodies and people of low public status with whom he constantly interacts. But this does not at all bother the Markan Jesus, since he lacks sensitivity for his own reputation, or concern for his public honour within the stereotyped honour-shame codes of the day. Jesus does not respect 'the boundaries or norms of the honor system and thus threatens social chaos' (Malina \& Rohrbaugh 1992:77). This is visibly demonstrated in 2:13-17 when Mark calls Levi, a tax-collector, to become one of his followers. Instead of 'making his association dependent on the conversion to the law' (Sanders, quoted in Murphy O'Connor 2007:67), Jesus accepts this archetypal sinner unconditionally and makes no demands for any kind of restitution. In the eyes of the religious elite, this implies that Levi still remains a sinner. The fact that Jesus also eats with him and his friends confirms their disgust at this public defilement. In turn, Jesus responds to the criticism of the scribes and Pharisees (who probably gather outside Levi's home to publicly shame Jesus from a 'ritually clean' distance) by saying that he did not come to call the righteous, but the sinners. Jesus' interactions with such ritually and ceremonially unclean persons thus serve as visual declarations of forgiveness (cf. 2:5). They are now the new significant others in the kingdom of God. They are the new honourable persons in this upturned understanding of honour and shame modelled by the Son of God.

\section{The purposeful walk to the cross}

A new epoch begins in 8:27-10:52 (the so-called 'discipleship catechism', according to Deppe 2015:233 ff.) with Jesus having accepted Peter's confession that he is the Messiah. In this section, framed by the phrase $\dot{\varepsilon} v \tau \tilde{n}$ ó $\delta \tilde{~}(8: 27 ; 10: 52)$, Jesus delivers three pivotal teachings to his disciples in which he shares the details and purpose of his messianic mission. He reveals to them that he is the Son of Man who must suffer at the hands of the religious leaders and the Romans and be put to death in Jerusalem, only to rise again from the dead after three days (cf. 8:31-33; 9:30-32; 10:33-34). These teachings take place while Jesus travels extensively. The term ódó $\varsigma$ is used seven times in these chapters, whereas 'three times in this section (8:31-38; 9:31-50; 10:32-45) "the way" is followed by Jesus' prediction and teachings about his coming sufferings in Jerusalem' (Gray 2008:14). The kingdom of God, as the central message of Jesus (1:15), cannot be separated from, or realised without this scandalous route to the cross. This is God's will to which Jesus, as the ever-obedient son of $a b b a$, his loving heavenly father, finally submits in Gethsemane (14:32-42). After his suffering, the Son of Man will be exalted to heaven and ultimately return on the clouds with great glory, as Jesus informs the high priest during his trial in Jerusalem (14:62; cf. also $8: 38 ; 13: 26$ ).

Although both hardship and glory define Jesus' role as the Son of Man, his earthly route from now on is paved with suffering, as it becomes clear between Mark 8:27 and 16:8. ${ }^{12}$ There can be no glory without tribulation, neither for Jesus, nor for his followers. They also have to drink his cup (10:35-45), before partaking in his heavenly glory. In exemplary fashion Jesus leads the way before his disciples en route to Jerusalem to face his predetermined path of suffering,

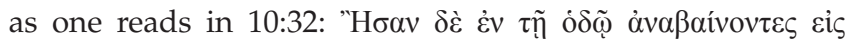

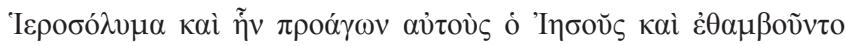
[and they were on the road, going up to Jerusalem, and Jesus was walking ahead of them, and they were amazed, and those who followed were afraid]. From now on the Jesus walk' attains a new sense of purpose and direction towards Jerusalem as his final destination where the fulfilment of God's plans awaits him, and where the purpose of his mission will be revealed. 'Neither Jesus' powerful teaching nor his miraculous works can display his complete identity. This picture of Jesus must be completed by a Suffering Servant crucified Messiah' (Deppe 2015:236).

The Jerusalem epoch of the Gospel (11:1-16:8) begins with Jesus' entry into Jerusalem amid a festive procession of

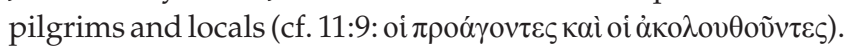
They sing Psalm 118, the well-known pilgrimage hymn about

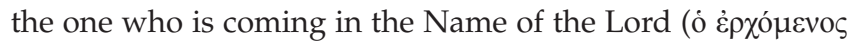
$\dot{\varepsilon} v$ óvó $\mu \alpha \tau$ кupíov). There is, however, a nationalist ring to their hymn, since they also sing about 'the kingdom of our father David that is coming' in verse 10. However, Jesus' mode of entry on a humble colt (cf. Gn 49:9; Zch 9:9) and his lack of any verbal response to their praises show that he has no intentions to reinstate a Jewish political kingdom in Jerusalem. He is the Son of God. He proclaims the kingdom of God. This is the only reason why he is now in the city of David, and why he also chose a colt to symbolically communicate the nature of his mission (cf. also Hartvigsen 2012:388ff.).

Purposefully and urgently Jesus follows the Lord's way, the

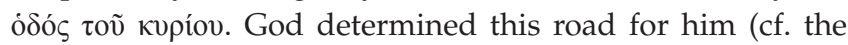
use of $\delta \varepsilon \tilde{i}$ in $8: 31 ; 9: 11 ; 13: 7-10 ; 14: 31)$, and John the Baptist prepared it for him (1:2-3). Therefore Jesus has no intention of deviating from this path now by living up to the political and nationalist expectations of the Jerusalem crowd. The 'coming' of Jesus to Jerusalem is solely to fulfil the plan of God, which entails the sacrifice of his own life for the sake of many. En route to the city, he already explained this to his

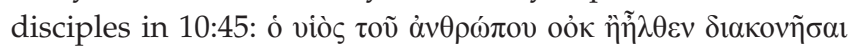

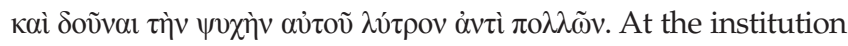
of the Lord's Supper on the Thursday evening, shortly before his crucifixion, Jesus tells them that he will be the 'sacrificial lamb' when he sacrifices of his own body and blood for many (14:22-24; cf. also Garland 2015:474-480).

Jesus has no further plans either for the Jerusalem cult, such as purifying their temple for further use. This much can be

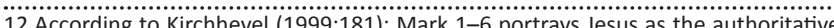
'Son of Man' perceived in Psalm 8. In Mark 8-14 there are nine 'Son of Man' passages that portray Jesus as the Suffering Servant of the Lord portrayed in Isa passages that portray Jesus as the Suffering Servant of the Lord port
$52: 13-53: 12$, even following the sequence of that passage' (p. 181). Cf., however, Chronis (2005:459ff.) and Reynolds (2008:66ff.) for different views. 
deduced from his symbolic act in the temple on the following day (11:15-19). Jesus' overturning the tables of the money changers is no temple cleansing, as headings in numerous Bible translations suggest, since he is no religious reformer. Jesus is the Son of God with the divine authority to decommission the temple. It has run its course. The temple is no longer suitable for sacrifices and for facilitating atonement between God and people; therefore Jesus prophetically overturns the tables of the money changers and calls it a den

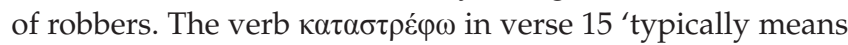
to destroy a place or building, and thus Mark describes Jesus' action with the provocative image of destruction' (Gray 2008:27). As was to be expected, this provocative deed signs Jesus' death warrant (11:8). The remainder of Mark's narrative focuses on his conflicts with the religious leaders and his own passion. One now reads in graphic detail how the followers of Jesus abandon him; how he is betrayed by Judas and denied by Peter; how the Jewish Council finds him guilty of blasphemy; how the Roman governor, Pontius Pilate, sentences him to death; and how he is finally crucified.

In Mark 15 the typically hurried and purposeful 'Jesus-walk' is brought to an abrupt end at the cross. More correctly, the purpose of his 'walk' all along was to bring him to this place of shame and rejection. ${ }^{13}$ As extremely brutal forms of execution that were accompanied by various forms of torture, which often preceded the actual crucifixion, '... including scourging, burning with or without pitch and heated plates (laminae)', crucifixions were reserved for enemies of Rome, as well as for low-life criminals and slaves (Cook 2014:418, 423). Thus when Jesus is crucified in Jerusalem, he more than ever embodies the obscurity of his mission. His humiliated and bruised body paradoxically reveals his self-sacrificing nature as the suffering Son of God.

In a world where individuals' bodies served as a 'microcosmic map of reality' (Glancy 2010:20), the naked and dying Jesus, stripped of all honour and godforsaken, is not merely a sign of the kingdom of God; it is thé sign, thé physical embodiment of the kingdom of God. Or, as Yoder (1972:61) famously puts it: 'The cross is not a detour or a hurdle on the way to the Kingdom, nor is it even the way to the kingdom; it is the kingdom come.' The obscurity of the Son of God dying on a cross is the ultimate expression of the true character of God. The cross of his Son once and for all reveals who he really is. At the same time it opens up a new form of atonement, as well as a radically new understanding of reality, including new categories of honour and shame. At the cross, the world is indeed turned upside down (cf. also Ac 17:6).

\section{The risen Jesus goes before his disciples}

Jesus dies in obscurity. However, his cry of desperation, quoted from Psalm 22:1, that God has abandoned him (15:34), but which also serves 'as an expression of trust in

13.According to Samuelsson (2013:270), crucifixion was '... a suspension, a completed or intended execution on a pole, with or without a crossbeam, and it ended in an extended death struggle'.
God's power to rescue an innocent sufferer' (Donnahue \& Harrington 2002:451), leads to an unexpected response from the centurion. As the Roman officer in charge of proceedings at the cross, and as the person responsible for making the crucifixion as gruesome as possible, his response is completely

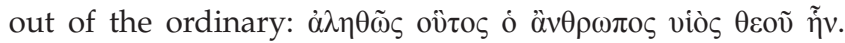
Whether meant as a positive confession, or ironically (cf. Van Oyen 2003:125ff.), the fact remains that this enigmatic, openended response should also be viewed in conjunction with other equally strange responses to the death of Jesus, such as the darkness that comes over Jerusalem (15:33), and the rending of the veil of the temple (15:38). It is as if 'the whole universe joins in mourning the cruel death of the Son of God' (Donnahue \& Harrington 2002:452). The sun cannot shine when the Son is dying, while the veil of the temple is also torn to signify the end of the temple era and the removal of God's glory, his shekinah from the holy place. While this is happening the Roman centurion's words about Jesus are correct. He confirms what God had said from the beginning $(1: 9-11 ; 9: 7)$, namely that Jesus is the Son of God. His identity shines through the obscurity of his bruised, now dead body. What God has known all along, and what the crowds have speculated about, is now clear. Jesus is who he said he is. Paradoxically the dead body of Jesus on the cross proves his true identity as Son of God.

As Jesus foretold his disciples, he is also raised from the dead on the third day. The mysterious young man dressed in a white robe (16:1-7) confirms this to the women at the empty

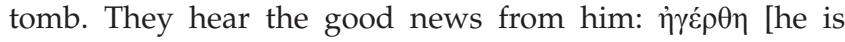
risen!]. He also adds the good news that, just as Jesus went before the disciples to Jerusalem (10:32), the risen Jesus is again on the road to go before them to Galilee ( $\pi \rho \circ \alpha \gamma \varepsilon 1$ v $\mu \tilde{\alpha} \varsigma$

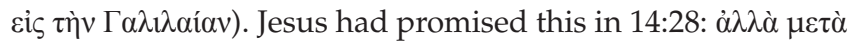

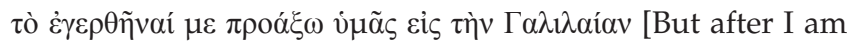
raised up, I will go before you to Galilee]. The women at the empty tomb are amazed, just as the disciples were en route to Jerusalem (10:32; cf. also the use of $\dot{\varepsilon} \kappa \theta \alpha \mu \beta \varepsilon \dot{\varepsilon} \omega$ in 16:5, 6). The man in the white robe now reminds the women to go and tell this good news to the disciples and to Peter (16:7). However, their amazement soon makes way for intense fear (cf. the use

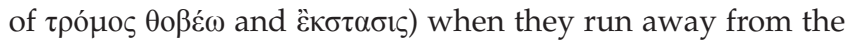
grave with the intention of telling nobody about it (16:8).

Despite this open-ended final verse of the Gospel, which leaves the intended readers guessing while simultaneously inviting them to bring closure to the story by means of their own narratives, ${ }^{14}$ it is clear that the enigmatic route of Jesus is now that of his followers. As Jesus earlier preceded his disciples to the cross in Jerusalem (10:32), the risen Jesus now precedes them into Galilee (16:7). Deppe (2015) declares:

Thus Mark intends to parallel a description of Jesus on his way to the cross with another description anticipating Jesus in his resplendent glory to indicate both the true identity of the Christ as well as the type of Messiah whom the community must purpose to follow. (p. 234)

14.'Mark's ending in 16:8 forces the hearers to fill in the unnarrated events, and they are able to do so from the clues that Mark has offered in what precedes but also from knowing the tradition that they have heard preached' (Garland 2015:547). 
The suffering Son of God on the cross, or as the man in the

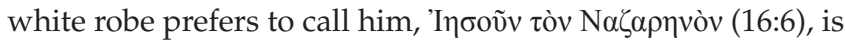
also the risen Jesus. He still is who he is, and he does what he has been doing all along. Mark does not express his identity in terms of a new glorified body, but in terms of his character and identity as the risen Jesus who continues to go before his disciples to Galilee:

... where it all began ... The baton has now been passed on to them. Jesus is not simply "a step ahead" of his failing disciples but "a journey ahead". (Garland 2015:558-559)

Their new challenge is to keep following the risen Jesus who has completed his enigmatic walk.

\section{Acknowledgements Competing interests}

The author declares that he has no financial or personal relationships which may have inappropriately influenced him in writing this article.

\section{References}

Beavis, M.A., 2015, Mark's audience: The literary and social setting of Mark 4.11-12, Bloomsbury, London.

Buxton, R., 2010, 'Metamorphoses of gods into animals and humans', in J.N. Bremmer \& A. Erskine (eds), The gods of Ancient Greece: Identities and transformation, pp. 81-91, Edinburgh University Press, Edinburgh.

Carroll, J., 2007, The existential Jesus. Scribe, Melbourne.

Chronis, H.L., 2005, 'To reveal and conceal: A literary-critical perspective on the Son of man in Mark', New Testament Studies 51, 459-481.

Cook, J.G., 2014, Crucifixion in the Mediterranean world, Mohr Siebeck, Tübingen. (WUNT 327).

Corbeill, A., 2004, Nature embodied: Gesture in ancient Rome, Princeton University Press, Princeton.

Decker, R.J., 2013. 'Markan idiolect in the study of the Greek of the New Testament', in S.E. Porter \& A.W. Pitts (eds), The language of the New Testament: Context history, and development, vol. 3: Earliest Christianity in its Hellenistic context, history, and development,
pp. 43-66, Brill, Leiden.

Deppe, D.B., 2015, The theological intentions of Mark's literary devices: Markan intercalations, frames, allusionary repetitions, narrative surprises, and three types intercalations, frames, allusionary repet
of mirroring, Wipf \& Stock, Eugene.

Donnahue, J.R. \& Harrington, D.J., 2002, The Gospel of Mark, Liturgical Press, Collegeville.

Dwyer, T., 1996, The motif of wonder in the Gospel of Mark, Sheffield Academic Press, Sheffield. (SSNTS 128).

Focant, C., 2012, The Gospel according to Mark: A commentary, Trans. from the French by L.R. Keylock, Pickwick Publications, Eugene.

France, R.T., 2002, The Gospel of Mark: A commentary on the Greek Text, Eerdmans, Grand Rapids.

Garland, D.E., 2015, A theology of Mark's Gospel, Zondervan, Grand Rapids.

Glancy, J.A., 2010, Corporeal knowledge: Early Christian bodies, Oxford University Press, London.

Gnilka, J., 1978, Das Evangelium nach Markus I/1 (Mk 1,1-8,26), Benziger Verlag, Zürich.

Graf, F., 2010, 'Gods in Greek inscriptions: Some methodological questions', in J.N. Bremmer \& A. Erskine (eds.), The gods of ancient Greece: Identities and transformations, pp. 55-80, Edinburgh University Press, Edinburgh.

Gray, T.C., 2008, The temple in the Gospel of Mark: A study in its narrative role, Mohr Siebeck, Tübingen. (WUNT II, 242).
Hanks, T., 2009, The subversive gospel: A New Testament commentary of liberation, Trans. from the Spanish by J.P. Doner, WIPF \& Stock, Eugene.

Harris, W.V., 2008, Dreams and experience in Classical Antiquity, Harvard University Press, Cambridge.

Hartvigsen, K.M., 2012, Prepare the way of the Lord: Towards a cognitive poetic analysis of audience involvement with characters and events in the Markan world, De Gruyter, Berlin.

Heil, J.P., 2000, The transfiguration of Jesus: Narrative meaning and function of Mark 9:2-8, Matt 17:1-8 and Luke 9:28-36, Editrice Pontificio Instituto Biblico, Rome. (AnBib 144).

Henrichs, A., 2010, 'What is a Greek God?', in J.N. Bremmer \& A. Erskine (eds.), The gods of Ancient Greece: Identities and transformation, pp. 19-42, Edinburgh University Press, Edinburgh.

Jenkyns, R., 2013, God, space and city in the Roman imagination, Cambridge University Press, Cambridge.

Joubert, S.J., 2015, 'Walking the talk': Paul's authority in motion in 2 Corinthians 10-13, In die Skriflig/In Luce Verbi 49(2), 7-15.

Kindt, J., 2014, Rethinking Greek Religion, Cambridge University Press, Cambridge.

Kingsbury, J.D., 1983, The christology of Mark's Gospel, Fortress, Philadelphia.

Kirchhevel, G.D., 1999, 'The Son of Man passages in Mark', Biblical Bulletin Review 9, 181-187.

Kobel, E., 2011, Dining with John: Community meals and identity formation in the fourth Gospel and its historical and cultural context, Brill, Leiden.

Lee, S.S., 2009, Jesus' transfiguration and the believers' transformation: A study of the transfiguration and its development in early Christian writings, Mohr Siebeck, Tübingen. (WUNT II, 265).

Malina, B.J. \& Rohrbaugh, R.L., 1992, Social-science commentary on the Synoptic Gospels, Fortress, Augsburg.

Martin, G., 2005, The Gospel according to Mark: Meaning and message, Loyola Press, Chicago.

Morrison, G.S., 2015, The turning point in the Gospel of Mark: A study in Markan christology, Clarke, Cambridge.

Moss, C.R., 2004, 'The transfiguration: An exercise in Markan accommodation', Biblical Interpretation 12, 69-89.

Murphy-O'Connor, J., 2007, Jesus and Paul: Parallel lives, Liturgical Press, Collegeville.

O'Sullivan, T.M., 2011, Walking in Roman culture, Cambridge University Press, Cambridge.

Prier, R.A., 1989, Thauma idesthai: The phenomenology of sight and appearance in archaic Greek, University Presses of Florida, Tallahasee.

Reynolds, B.E., 2008, The apocalyptic Son of man in the Gospel of John, Mohr Siebeck, Tübingen. (WUNT II, 249).

Samuelsson, G., 2013, Crucifixion in antiquity: An inquiry into the background and significance of the New Testament terminology of crucifixion, 2 nd rev. edn., Mohr significance of the New Testament
Siebeck, Tübingen. (WUNT II, 310).

Schnelle, U., 2013, Einleitung in das Neue Testament, 8. Aufl., Vandenhoeck \& Ruprecht, Göttingen.

Shiner, W., 2003, Proclaiming the gospel: First-century performance of Mark, Trinity Press International, Harrisburg.

Shively, E.E., 2012, Apocalyptic imagination in the Gospel of Mark: The literary and theological role of Mark 3:22-30, Walter de Gruyter, Berlin.

Stein, R.H., 2008, Mark, Baker Academic, Grand Rapids.

Tàrrech, A.I., 2012, 'The glory on the mountain: The episode of the transfiguration of Jesus', New Testament Studies 58, 151-172.

Thielman, F. 2005, Theology of the New Testament: A canonical and synthetic approach, Zondervan, Grand Rapids.

Van Oyen, G., 2003, 'Irony as propaganda in Mark 15:39?', in P.W. van der Horst, M.J.J. Menken, J.F.M. Smit \& G. van Oyen (eds.), Persuasion and dissuasion in early Christianity, ancient Judaism, and Hellenism, pp. 125-142, Peeters, Leuven.

Wallace, M.I., 1995, The second naiveté: Barth, Ricoeur, and the new Yale theology, Mercer University Press, Macon.

Winn, A., 2008, The purpose of Mark's gospel: An early Christian response to Roman imperial propaganda, Mohr Siebeck, Tübingen. (WUNT II, 245).

Wrenhaven, K.L., 2012, Reconstructing the slave: The image of the slave in ancient Greece, Bloomsbury, New York.

Yoder, J.H., 1972, The politics of Jesus, Eerdmans, Grand Rapids. 